\title{
DR THOMAS BEDDOES AND JAMES WATT: PREPARATORY WORK 1794-96 FOR THE BRISTOL PNEUMATIC INSTITUTE
}

\author{
by \\ DOROTHY A. STANSFIELD* AND RONALD G. STANSFIELD $†$
}

\section{PART I. BEDDOES' THEORIES, HIS WORK, THE INTERVENTION OF JAMES WATT}

In 1793, Dr Thomas Beddoes moved from Oxford, where he had won a considerable reputation as Chemical Reader, and established himself as a physician in Bristol. This was not an easy period for him, since he had a reputation for being an active sympathizer with the French Revolution and was known to the Home Office as the author of anti-government pamphlets sufficiently subversive to merit investigation. Not surprisingly, the University authorities, on the advice of the Home Office, had felt obliged to abandon a proposal that Beddoes should remain in Oxford while a University Chair of Chemistry was established. ${ }^{1}$ Beddoes had been prepared to postpone plans of his own, but in the changed circumstances he returned to the purpose which had originally led him to decide to leave Oxford. This was to test in practice the possibility that gases might be found useful in the treatment of, in particular, pulmonary tuberculosis, and he arrived in Bristol with a clear plan in mind. He settled near to the Hotwells, where many sufferers from tuberculosis were gathered in the hope of a cure, and built up a practice that would support him, for he had undertaken not to derive any income from his work for the pneumatic project.

In the same year (1793), he published three papers, ${ }^{2,3}$ which explained the scientific thinking behind pneumatic medicine, showed what had already been attempted, and endeavoured to allay fears that his experiments were dangerous and irresponsible. Concurrently, he planned to use gases in treatment and to make trials of suitable breathing apparatus. The essays made public Beddoes' plans, but accounts of his work as a doctor appear mostly in private letters.

*Part I, by Dorothy A. Stansfield, BA; †Part II, by Ronald G. Stansfield, MA, BSc; 62 Warwick Road, Bishop's Stortford, Herts CM23 5NW.

${ }^{1}$ T. H. Levere, 'Dr. Thomas Beddoes at Oxford, radical politics 1788-93 and the fate of the Regius Chair in Chemistry'. Ambix, 1981, 28: 61-69. D. A. Stansfield, Thomas Beddoes M.D. 1760-1808, Dordrecht, Reidel, 1984. But see also, A. V. Simcock, The Ashmolean Museum and Oxford science, 1683-1983, Oxford, Museum of the History of Science, 1984, p.35, note 91.

2 Observations on the nature and cure of calculus, sea scurvy, catarrh and fever, London, Murray, 1793 (hereinafter referred to as Observations).

${ }_{3}$ A letter to Dr. Darwin on a new mode of treating pulmonary consumption, Bristol, Bulgin \& Rosser, 1793; Letters from Dr. Withering, Dr. Ewart, Dr. Thornton and Dr. Biggs together with some other papers by ... Thomas Beddoes, London, Murray \& J. Johnson, 1793. 


\section{Dr Thomas Beddoes and James Watt}

The death of perhaps Beddoes' best-known, certainly his most pathetic, patient, fifteen-year-old Jessie (Janet) Watt, is the subject of correspondence among his more senior friends, James Watt, Joseph Black, ${ }^{4}$ and Erasmus Darwin. ${ }^{5}$ In addition there are a number of unpublished letters by Beddoes himself to James Watt, written in the years 1794-96 and preserved in the Watt Collection at Doldowlod, ${ }^{6}$ the house near Newbridge-on-Wye to which Watt retired when he left Birmingham. These hurried and enthusiastic letters with their details of the preparations for the final stage of Beddoes' experiment - the Pneumatic Institute itself-form the subject of this paper. They amplify what is already known from the published letters and give us a lively picture of Beddoes at work in these three all-important years. An account of the scientific and technical help that Watt gave Beddoes at this time is to be found in Cartwright's authoritative paper. ${ }^{7}$ This draws on Watt's contributions to Considerations (1795). ${ }^{8}$ The account of this period in my recent biography of Beddoes ${ }^{9}$ made use of these letters as well as the published work of the 1790s. The manuscript letters merit, nevertheless, a more detailed description and fuller quotation than was possible in the broader survey. They describe Beddoes' day-to-day work, bringing before us vividly his efforts on behalf of his patients, his concern to perfect the breathing apparatus needed for treatment with gases, and the extent to which he was able to contribute from his own experience. Even if we turn to Beddoes' description of the breathing of gases in the report of his work which he made for the managers of the Pneumatic Institute, our hopes for lively description of the patients are disappointed. The 1799 Notice of some observations at the Pneumatic Institute ${ }^{10}$ contains only sketchy accounts, entirely lacking the liveliness of the letters; the more vivid descriptions there are those concerned with the breathing of nitrous oxide by healthy subjects, including Beddoes himself.

Beddoes' letters bring to life the detailed and sometimes tiresome work of preparing for publication the last two issues of Considerations. Since Beddoes always avoided risk in using gases as medicine, the letters give information concerning the other medicines and treatments used, putting the inhalation medicine in context. The aim of establishing a hospital is fully accepted in this correspondence but the activities for which in the end it became famous, or perhaps notorious, are not anticipated. The extent to which the scientific work would develop, the choice of Humphry Davy as superintendent and its consequences are not even foreshadowed, and naturally the hilarity produced by breathing "laughing gas" was not imagined; nitrous oxide was not among the gases mentioned as being used in treating patients. The silence of these

\footnotetext{
${ }^{4}$ E. Robinson and D. McKie (editors), Partners in science. Letters of James Watt and Joseph Black, London, Constable, 1970.

5 D. King-Hele (editor), The letters of Erasmus Darwin, Cambridge University Press, 1981.

${ }^{6}$ Quoted by kind permission of Lord Gibson-Watt.

${ }^{7}$ F. F. Cartwright, 'The association of Thomas Beddoes, M.D. with James Watt, F.R.S.', Notes Rec. $R$. Soc. Lond., 1967, 22: 131-143.

8 Thomas Beddoes and James Watt, Considerations on the medicinal use and on the production of factitious airs; Part I, by Thomas Beddoes, M.D., Part II, by James Watt, engineer; 2nd ed., Bristol, Bulgin \& Rosser for J. Johnson (London), 1795 (hereinafter referred to as Considerations).

${ }^{9}$ Stansfield, op. cit., note 1 above, ch.9.

${ }^{10}$ Bristol, Briggs \& Cottle; London, Longman \& Rees.
} 


\section{Dorothy A. Stansfield}

early letters on these matters brings home what a tragi-comedy developments at the Pneumatic Institute became in contrast to the original hopes and activity.

At the projected Pneumatic Establishment, scientific investigations and medical treatment would be carried out side by side. Various conditions, apparently incurable, were to be treated, but though it had been expected that foremost among them would be pulmonary tuberculosis, in the event, most of the patients suffered from some form of paralysis. With the opening of the Pneumatic Institute in 1799, Beddoes reached the point where he hoped to demonstrate without doubt, since conditions would be suitably controlled, the medical power of gases and the feasibility of administering medicine by inhalation. By 1798, it was clear that interest in this form of treatment was widespread. Between 1792 and 1798, Beddoes collected and published many "case histories" sent him by well-wishing physicians from many parts of the country. ${ }^{11}$ They had all made some trial of gases, but independently of one another and unsystematically. Beddoes was concerned to bring supporting evidence from as many physicians as possible; he was unfortunately so eager that he chose the cases very uncritically. From his own experience he took for full description only the case of a young boy who, though finding relief from airs, died, as Beddoes felt, because the attendant could not manage the breathing apparatus. The most dramatic account is of his own inhalation of oxygen over a long period. ${ }^{12}$ Later in the 1795 and 1796 editions of Considerations there are brief accounts ${ }^{13}$ of three of Beddoes' patients. Beddoes had mostly made trials of oxygen or of hydrogen. That the gas principally used at the Pneumatic Institute from its earliest days was neither of these but nitrous oxide was due to the special interest of the unknown young man Beddoes chose as the superintendent of his laboratory, nineteen-year-old Humphry Davy.

Davy had already decided upon medicine as his career and in 1795 had become apprenticed to the Penzance surgeon, Bingham Borlase. He also embarked on an ambitious programme of study designed to equip him to follow his apprenticeship with a period at Edinburgh University. In 1797, he began to work at chemistry, and tested the theories of heat and light which Lavoisier put forward in his Traité élémentaire. Davy was able to use the laboratory of a family friend, Mr Tonkin, but had to construct his own apparatus. In March 1798, his curiosity was aroused by dramatic statements made in Samuel Latham Mitchell's Remarks on the gaseous oxyd of nitrogen and its effects $(1795)^{14}$ that nitrous oxide had disastrous effects whether inhaled or in contact with the skin, that it was indeed the very "principle of contagion". Davy accepted the challenge, made a number of experiments, and dared to breathe the gas himself. Mitchell's book provides the link between Beddoes and Davy. Davy had probably read Mitchell's account in Part V of Considerations, where Beddoes published it as an appendix, and he would have had another reason to discover this work by Beddoes and Watt. During the winter 1797/8, Gregory, Watt's younger son, was living in Davy's mother's house, and a friendship most fortunate for Davy was begun. Gregory Watt encouraged Davy to write about his experiments to Beddoes in

${ }^{11}$ See notes 2 and 3 above.

12 Letter to Darwin, op. cit., note 3 above, p. $31 \mathrm{ff}$ and p.50ff.

${ }_{13}$ Considerations, 1795, Part I, p. 158; 1796, Part III, pp. 48, 77.

${ }^{14}$ Published in New York at a time when epidemic fevers were causing much concern. 


\section{Dr Thomas Beddoes and James Watt}

Bristol. Davies Giddy of Tredrea, ${ }^{15}$ to whom all the plans for the pneumatic experiment had been described from its very inception, noticed and encouraged Davy at about the same period. Besides being an influential figure in Cornwall, Davies Giddy was Beddoes' most intimate friend. He had attended Beddoes' lectures in Oxford and would well understand what sort of man he needed as the "operator" in his laboratory. Davy's own letters and experiments and a recommendation from Giddy convinced Beddoes that Davy was the man he needed-no theoretician but a skilful experimenter who would involve himself in the work of the laboratory. Once settled in Clifton with equipment beyond anything he had had before, Davy turned again to his work on nitrous oxide. The result was fortunate for Davy but embarrassing for Beddoes. During the years when the Institute was active, 1798-1801, the uncontrolled and bizarre behaviour of those experimental subjects who breathed this "laughing gas" attracted greater attention than all its other researches.

There was room in the Dowry Square house for some eight patients; others were to receive their treatment as outpatients. Once Davy had shown conclusively that nitrous oxide could be breathed safely, trials were made with a number of subjects, in addition to the other medical and scientific work at the Institute. The effects of breathing "laughing gas" are now so well known that it requires some effort to imagine how astonishing they were in 1799. The excitement of this novel experience led to a cult of breathing the "heavenly air" expressly for the enjoyment of moments of "heightened sensibility", and Beddoes' hospital was rendered ridiculous. Yet in after years, the Institute has always been remembered as the nursery of Humphry Davy's experimental talents and the place where he carried out the systematic study of the various oxides of nitrogen, his first substantial achievement as a chemist. Beddoes' laboratory and his encouragement made possible these experiments, which Davy finally described with remarkable clarity and authority in his Researches, chemical and philosophical, chiefly concerning nitrous oxide, or dephlogisticated nitrous air, and its respiration (London, Murray, 1800).

Beddoes' Pneumatic Institute was the climax of the search for a pneumatic medicine which accompanied developments in the chemistry of gases in the closing years of the eighteenth century. From mid-century, the major gases, carbon dioxide, hydrogen, oxygen, and nitrogen, had been isolated; air had been recognized as a mixture and its component gases had been identified; in 1785, Lavoisier had worked out the proportions in which they were present in the atmosphere. This, with the changed understanding of combustion which showed that in burning, substances combined with oxygen, had suggested the possibility that gases might be of use in medicine and that they might be administered to the patient by inhalation. This "new" medicine also took account of developments in the understanding of respiration. Beddoes was well placed to follow these developments. He had entered Pembroke College, Oxford, in 1776, when he was sixteen, and from 1781 went on to medical studies, first in London, and then from 1784 to December 1786 in Edinburgh, where Joseph Black's chemistry course impressed him. He valued Black's originality and discoveries-Black had co-operated with James Watt in work on latent heat, had discovered carbon dioxide,

\footnotetext{
15 On his marriage in 1808, Giddy took his wife's name, becoming known as Davies Gilbert. President of the Royal Society, 1827-30.
} 


\section{Dorothy A. Stansfield}

and applied the discovery to the cure of the stone-and he admired the skill of Black's demonstrations. For John Brown's lectures on his new theory of excitability, which were attracting large audiences, Beddoes expressed a certain scorn. He despised as well the quarrels over theory between Brown's followers and those of William Cullen; to Beddoes, these disputes were a distraction from the healing tasks of medicine. From Edinburgh, Beddoes returned to Oxford, where his first interest was in the chemistry of respiration and he corresponded with William Goodwyn, author of The connection of life with respiration (1788). In 1787, William Austin's removal to London opened the way for Beddoes to become Chemical Reader. He kept in close touch with Black, following his style of teaching and consulting him about drawing up a syllabus which would do justice to the new knowledge about the properties of gases and the nature of combustion. He must from the beginning have had in mind the hope for a "pneumatic medicine" since he is known to have included it in his lectures and, before he left Oxford, had prepared the first paper on the subject. ${ }^{16}$ In this work, Beddoes was ambivalent about Brown's doctrine of excitability, making use of it at some points but rejecting it during the course of his account of Dr Christoph Girtanner's publication On the laws of irritability. ${ }^{17}$ Brown's doctrine, that external stimuli alone determined the state of disease or health, was useful for Beddoes when he wished to justify the giving of "airs". Oxygen as a stimulant and air with a decreased proportion of oxygen as a depressant, would be found to alter a patient's condition in the same manner as the more traditional pair, alcohol and opium. Beddoes' treatment would at least appear to relate to Brown's two types of illness, the asthenic needing a stimulant and the sthenic a depressant. He could argue that the bright complexion of consumptive patients indicated an excess of oxygen in the blood, which could be corrected by the giving of an appropriate gas. Beddoes' reputation was to suffer from his countenancing Brown's theory, soon to be discredited.

Beddoes combined with his extensive knowledge of this theoretical background a good understanding of the technical problems involved in pneumatic medicine. Apparatus would be needed for the production and storage of gas and for inhalation by patients and by subjects in experimental trials. This needed to be simple, as it might be used by unskilled attendants. It also needed to be acceptable to the patients. Beddoes had considerable skill as an experimenter in the laboratory. His Oxford lectures were illustrated by experiments for which he sought the most up-to-date apparatus and he had had opportunity to see, in the industries of the Midlands and the iron foundries of his native Shropshire, the practical application of scientific principles. Early in his medical practice in Bristol, he devised simple apparatus for trials of inhalation medicine.

Beddoes' letters, except on two occasions, are about events after he had settled in Bristol. Two letters have the different purpose of making clear to Watt the agreements he had already entered into. In these, Beddoes referred back to the arrangements he had made with his friends during the hiatus in his career between leaving Oxford and

${ }^{16}$ Op. cit., note 2 above.

${ }^{17}$ Christopher Girtanner (1760-1800) published the first German version of the Méthode de nomenclature chimique (1787), and a German textbook modelled on Lavoisier. See Stansfield, op. cit., note 1 above, pp. $27,148$. 


\section{Dr Thomas Beddoes and James Watt}

setting up practice in Bristol Hotwells. To develop a new career in any worthwhile manner, he had needed to put forward a clear scheme which would arouse public interest. His three friends in the Midlands, William Reynolds, ${ }^{18}$ Dr Erasmus Darwin, and Dr Yonge of Shifnal, Beddoes' home, gave their names and their financial backing to the first plan for a "Pneumatic Establishment", and Beddoes was able to bring this forward when Watt needed to secure the co-operation of his partner, Matthew Boulton. Beddoes made clear what had been arranged in a letter dated 17 August 1794: "Mr. Boulton mentioned an objection to anything like an hospital. Certainly a number of sick in one room is very objectionable; but I hope, if this scheme takes place there will never be above two in one room; and I think unless you have a few patients under your eye you cannot fully ascertain the power of airs, particularly the effect of an atmosphere slightly modified but inspired for a long time." Beddoes could also encourage Watt and Boulton by showing that careful financial provisions had been agreed at the outset. In July 1795 , he told Watt exactly how he had committed himself to William Reynolds and Dr Yonge. Each of these friends and Joseph Reynolds, William Reynolds' half-brother, would contribute $£ 200$, Beddoes himself putting in a fourth $£ 200$. A house suitable for a laboratory, and with accommodation for occasional patients, would be rented. Beddoes was to be in charge of the whole establishment and was to engage assistants. He had already engaged a man and set up a large apparatus, and he estimated that house rent and coal would cost more than $£ 100$ each. Beddoes expressed his willingness that all this should be published. The letters show a growing optimism, even certainty. Writing of the new edition of Considerations, he hoped it would exhibit "effective progress in pneumatic medicine and laying the foundation for the practice". He was confident that "This is more than ever was done in the same time in so difficult and important undertaking and more infinitely than would have been done if you had not interfered."

Beddoes felt the need to explain his business arrangements some five months after the correspondence began. When he first wrote, he must have felt that he could approach Watt because the initial difficulties had been overcome. He had many patients in and around Bristol and he had carried out his plan of following up his early Observations with further papers setting out the observations, chemical experiments, and clinical trials by which he sought to justify his hopes for pneumatic medicine. His position in Bristol was strengthened by the friendship of Richard Lovell Edgeworth, ${ }^{19}$ to whom he had been introduced by James Keir. ${ }^{20}$ Beddoes had visited Keir's Tipton works in 1791, and was keenly interested in the processes of the soap manufactory and in discussion of Keir's Chemical dictionary. Keir had just finished a biography of Thomas Day (1748-89), the author of the children's book Sandford and Merton and a fellow-member of the Lunar Society. Finding that Beddoes was an enthusiastic

\footnotetext{
18 William Reynolds (1758-1803), ironmaster; had the management of the Darby family's ironworks at Coalbrookdale. His experiments on the production of steel were observed by Beddoes. See his 'An account of some appearances attending the conversion of cast into malleable iron', Phil. Trans. R. Soc. Lond., 1791, 81: 173-181; 'Further observations on the process for converting cast into malleable iron', ibid., 1792, 82: 257-269.

19 Richard Lovell Edgeworth, FRS (1744-1817), of Edgeworthstown, County Longford, Ireland.

20 James Keir (1735-1820), chemist; adviser to M. Boulton and later manager of his Soho works. Keir set up his own chemical works and soap manufactory at Tipton.
} 


\section{Dorothy A. Stansfield}

admirer of Day and of his ideas, Keir realized that he would be welcomed by Edgeworth, who had been Day's most intimate friend and had, like him, been for a while seduced by Rousseau's educational methods. Although an eccentric and an inventor, Edgeworth was sufficiently an aristocrat to be acceptable. He was politically discreet and able to help Beddoes, hoping "the fat little democrat" would learn to curb his political enthusiasms. But the meeting led to more than formal introductions into Bristol society. Beddoes attended Edgeworth's son, Lovell, who had been brought to Clifton in hope of cure of his tubercular condition. He met members of the family: Edgeworth's third wife, the younger children, and, looking after them, their stepsister Maria, Edgeworth's most famous daughter. Anna, Maria's younger sister, was nursing Lovell and by May 1793, Beddoes was deeply in love with her. Edgeworth appears to have been happy about their marriage and it was Beddoes who suggested that eighteen-year-old Anna should spend a year at home at Edgeworthstown before making a final decision. Some time during the next year, a miniature portrait of Beddoes was painted by S. T. Roche. ${ }^{21}$ It shows a fashionably dressed young man, striped waistcoat and shirt frill showing beneath a tidy coat. The expression is firm, but at the same time humorous; the only hint of "revolutionary" spirit is the informally arranged hair. There is a charm and grace in the miniature which suggests that it may have been made for the occasion of his marriage. Beddoes had not yet developed the stern air of the later and better-known pastel drawing by James Sharples in the Bristol City Art Gallery. We sense in the miniature the optimism of the time when Beddoes' plans were coming towards fulfilment and when he had the confidence to turn to James Watt for help. The letters he wrote in the following years, full of practical details, convey his buoyant, eager mood. Beddoes' first letter to Watt was written on 4 March 1794, shortly before he travelled to Edgeworthstown for his wedding with Anna. He must have been full of hope that on his return he could make good progress on the last stage of his work and soon see the Pneumatic Establishment in being. The wholeheartedness of Watt's participation was more than he could have hoped for.

This first letter made it clear that he was proposing no more than an experiment. He wrote of his physiological discoveries confirming some of John Hunter's speculations; of his hopes of forming a new and true system of animal nature, and was candid about his difficulties. "I do not believe in my own theories-for instance, I do not believe in the hyperoxygenation of the system in consumption-My first speculations were merely attempts to put facts together and to deduce such conclusions as might be put to the test of exp[eriment]. I endeavoured to draw these speculations up in a plausible form, otherwise how would they have gained attention? Otherwise how could good in any reasonable time have resulted from them?" This suggests that Beddoes was so clear in his own mind that his aim was the reasonable one of testing the physiological effects of gases and exploring their medical potential, that he could put forward the hyperoxygenation principle as a possible explanation because it too would be subject to experiment. The need for a "plausible form", though it may have the air of meaning to deceive, is more acceptable when we remember that Beddoes hoped to reach a

\footnotetext{
${ }^{21}$ National Portrait Gallery, London. Purchased in 1976, it appears to have been in the family of Emmeline King (nee Edgeworth), Anna Beddoes' sister.
} 


\section{Dr Thomas Beddoes and James Watt}

general public and to gather in subscriptions as well as arouse interest. Watt must have been content with Beddoes' way of ensuring that his plan "gained attention", for nowhere does Beddoes refer to the problem of describing the experiments without in any way appearing to promise a cure. Beddoes' approach to Watt was made when he realized he needed to improve the breathing apparatus. He knew from his own trial breathing machines how important this was for successful treatment. The tone of the first letter, on 4 March 1794, is formal. Beddoes referred to the forthcoming Considerations and proposed to visit Watt at Heathfield, Watt's Birmingham home. Beddoes must have felt that his work was well developed for him to lay his plans before a man as eminent as Watt.

From March until the beginning of November 1794, Beddoes wrote rather more than once a week and the letters continued to be frequent in the first half of 1795 . In the twelve months from July 1795 to July 1796 , when the last letter in the series was written, Beddoes wrote at longer intervals. In October 1797, after a long time, there comes a letter which again refers to pneumatic medicine but its main subject is Beddoes' public lecture in Bristol. ${ }^{22}$ The early letters describe his experiences with patients breathing "airs"- oxygen, hydrogen, fixed air (carbon dioxide), and hydrocarbonate (water gas, i.e. carbon monoxide and hydrogen)-and his problems with the breathing apparatus. Late in 1794 and again in 1795, there is much consultation over the production of Considerations. The early discussions must refer to the publication of October 1794, when Watt was writing a second part. Later, a paper published by Watt in 1795 and Part V of Considerations are being arranged.

In the last days of Jessie Watt's illness, on the advice of Erasmus Darwin, Beddoes had been called in to try the new treatment. A moving letter from Watt to his old friend Joseph Black describes how airs had been given, but apparently there was no apparatus to use at short notice:

My Amiable and lovely daughter expired on Friday morning after long suffering, the fever she had when I wrote you last proved a hectic of the most violent kind, which perhaps we might have seen sooner if we had not been misled by her violent hystericks. On perceiving a change in the expecturated matter I sent for Dr. Darwin who gave little hopes but prescribed for the fever and other urgent symptoms. I then had Dr. Beddoes who attended her daily for a week, but also seemed to think the case desperate. She breathed fixt air from effervescing mixtures placed near her and sometimes inhaled it mixt with atmosphere, but without other apparent effect than its being grateful to her. The violence and fever the hystericks and her great weakness prevented our trying the effect of other airs and some attractive medicines. (9 June 1794)

James Watt's letter of thanks (30 June 1794) for Erasmus Darwin's condolences on the death of Jessie makes clear how he came to the decision to help Beddoes:

I have long found that when an evil is irreparable, the best consolation is to turn the mind to any other subject that can occupy if for the moment. This is not always possible but we must make the best of our imperfect nature and do what lies in our power. I told you that I had turned my contemplations to the subject of medicinal airs; not from any idea that I understood the subject, but because nobody else does, and therefore that my hints might by chance be as good as another

${ }^{22} \mathrm{~T}$. Beddoes, Introductory lecture to a course of popular instruction on the human body, Bristol, J. Cottle, 1797.

${ }^{23}$ Robinson and McKie (editors), op. cit., note 4 above, letter 144. 


\section{Dorothy A. Stansfield}

man's. Where a regular physician professes the ignorance, a quack may safely be called in, and Dame Fortune suffered to throw the dice. I have made an apparatus for extracting, washing and collecting of poisonous and medicinal airs. I mean to send you an apparatus, with which you may try the whole round of poisonous and salutiferous airs; and I hope, in your hands, not without success.... I have written a short list of my hints for Dr. Beddoes, and am sending him an apparatus, a description of which he means to insert in his next publication. I should object to this, because it is in a manner untried; but as it is likely to answer, I cannot withhold anything which may be of use in prompting others to do better.

The last lines here must refer to two letters from Beddoes, written on 14 and 26 June and now at Doldowlod, from which we see how Beddoes was touched and gratified, but anxious lest his treatment of Jessie Watt might be thought to have contributed to her death. He wrote on 9 June 1794:

I was sincerely grieved on account of the event $\mathrm{Mr}$. Barr ${ }^{24}$ communicated to me. I felt the suddenness of Miss Watt's death as a great disappointment. I did not expect to hear from yourself so soon, if at all your letter gives me much satisfaction and makes me wish much for the advantage of personal communication with you while you are thinking upon the subject of airs.... I wish to know the concluding symptoms in order to form a judgement whether any of the peculiarities in the mode of treatment may be suspected of doing harm and on this point I wish your opinion. Poor Mrs. Watt. I wish I could suggest something interesting enough to engage her mind.

On the 14th he wrote again: "I am truly concerned to hear that sorrow hangs more heavily upon your mind than immediately after your loss. My principal reason for troubling you for particulars was, as I believe I mentioned, to be able to judge whether the inspiration of fixed air could be suspected of having done injury."

It is clear that the offer of help was unexpected and that Beddoes immediately recognized how Watt's support would strengthen him in the face of opposition from "physicians who are almost as inveterate against me as they were against the discoveries of the circulation of the blood." From this point Watt entered without reserve into all Beddoes' preparations.

The support and friendship of so respected a public figure as Watt and the practical importance of his technical skill clearly encouraged Beddoes. There were additional reasons why Beddoes was so gratified and surprised when Watt first offered his help. Though the friendship of Richard Lovell Edgeworth and marriage to his daughter Anna had smoothed the way for Beddoes in his early days in Bristol, prejudice against him was long-lasting. Dislike of his politics and of his abrupt manner increased resistance to his trials of gases. Beddoes' friends had misgivings on this account; Black, for example, writing to Watt in October 1794 to promise to subscribe four or five guineas to "a small hospital where the usefulness of Gas's might be put to a fair trial", commented, "In my opinion he does not do well to get into quarrels and disputes if they can possibly be avoided." 25 For a while after his arrival in Bristol, Beddoes concentrated on his medical practice, but at the end of 1795 he was unable to restrain himself from taking a conspicuous part in protests in the city against the government's determination to curb freedom of assembly and publication. The two measures

\footnotetext{
${ }^{24}$ James Barr, a Birmingham apothecary/surgeon. He attended Watt's family. Letters from him appear in Considerations, Part I, p. 66, and Part III, p. 132. The second describes the treatment of Watt's servant, Rebecca Stanley.

${ }^{25}$ Robinson and McKie (editors) op. cit., note 4 above, letter 150.
} 


\section{Dr Thomas Beddoes and James Watt}

proposed, subsequently known very appropriately as the "Gagging Acts", ${ }^{26}$ aroused widespread opposition, and protest meetings were held in many towns. The Bristol meeting on 20 November 1795 was chaired by a very respectable Quaker doctor, Edward Long Fox, and Beddoes was justified in feeling that by his criticism of the government on this occasion he was taking part in an expression of moderate opinion. Watt had written to Sir Joseph Banks, President of the Royal Society, hoping to persuade him to support Beddoes. Watt's son, James junior, wrote in confidence to Beddoes of his father's efforts with Banks, ${ }^{27}$ his own opinion being that, though Banks had written that he was not convinced of the soundness of Beddoes' ideas, he had "traced [Beddoes'] cloven Jacobin foot and does not choose to patronise any new fangled innovations, which although the event be different, proceed from the same perturbed spirit. Be it as it is, your case is truly lamentable and I recommend an additional dose of Oxygene to keep up your spirits upon this disappointment!"

James Watt junior continued the enthusiasm which some time before had led his father to confide in Black: "My son James's conduct has given me much uneasiness tho' I have nothing to accuse him of except being a violent Jacobin, that is bad enough in my eyes, who abhor democracy, as much as I do Tyranny, being in fact another sort of it. Young men will however presume to think for themselves and of all their father's possessions set least store upon their experience. I much dread the consequences of the opinions on Government which have been propagated of late with so much industry. The Rabble of this country are a mine of Gunpowder that will one day blow it up and violent will be that explosion." ${ }^{28}$ It is a witness to the strength of Watt's desire to help in the search for a cure for pulmonary tuberculosis that holding such opinions, he devoted so much time to the breathing apparatus. On his side, Beddoes was beginning to be disillusioned by the violence in France. Out of a sense of responsibility to the airs project and its patrons he felt the need to be cautious and to stand on sure political principles, and on Christmas Day 1795 he wrote to James Watt senior to explain:

I know well that my politics have been very injurious to the airs. Mr. Keir today furnished me with a striking proof if any were wanting. Yet as every stroke aimed at liberty equally threatens science, morals and humanity, it requires great self-denial to look on patiently and silently when such great interests are at stake. On the last occasion the adversaries of Mr. Pitt stood on more popular ground than ever before. I therefore think I did no harm to the other cause. I hope too that in endeavouring to animate the public spirit $I$ have done something to repress vengeance and calm violence. At least I can say that no Bristol publication ${ }^{29}$ has been so eagerly and generally read.

Wisely, Beddoes found good reasons for remaining at home and not joining James Watt junior in canvassing support in London, even though he was warmly invited: "If you were to come here [Soho] for the day and then go with me to London, we might do some good! If you come you will of course come with your luggage etc. and directly to

\footnotetext{
${ }^{26}$ The Treasonable Practices Bill, introduced by Lord Greville, and the Seditious Meetings Bill, introduced by Pitt, 1795.

27 Copy Press Letter Book, Doldowlod.

28 Watt to Black, 17 July 1793, Robinson and McKie (editors), op. cit., note 4 above, letter 139.

29 The Bristol publication must have been his two pamphlets, written at a high pitch of emotion at the time of the protest meeting: In defence of a Bill of Rights, 19 and 21 November 1795, and Where would be the harm of a speedy peace? 9 December 1795. Although more reasonable in tone than Beddoes' earlier writings, they were still so vigorous that the description of their aim as to "calm violence" seems näıve.
} 


\section{Dorothy A. Stansfield}

my father." ${ }^{30}$ Nevertheless, Beddoes continued to attack the government, publishing in the summer of 1796 a severely critical Essay on the public merits of Mr. Pitt. Black was provoked to comment, "I am sorry to see that Beddoes is so absurd and wrongheaded as to set himself up as a statesman and attack Mr. Pit [sic]. It must proceed either from a foolish conceit of his own abilities and Judgement or from a mean design to court a party."31

We can see the outcome of Watt's “interference", as Beddoes called it in July 1795, if we take together the parts of Considerations published in 1794, 1795, and 1796 and look back at the development they reveal. Part I was in effect the essay described in the letter of March 1794 which Beddoes hoped would arouse Watt's interest. A second part bearing Watt's name was published with this, giving rise to the double title Considerations on the medicinal use and on the production of etc. In Part III, 1795, where the names of both Beddoes and Watt appear as authors, there is a relatively brief contribution by Watt. This part is a curious publication containing satirical verses and a "spoof" letter by Beddoes designed to satirize the prejudice and conservatism that riled him so in the medical profession. They are amusing but quite out of place-one wonders what could have been Watt's feelings. In October 1796, there appeared in Clifton, printed by Bulgin \& Rosser for Johnson, Medical cases and speculations including parts IV and $V$ of Considerations etc. by Thomas Beddoes MD and James Watt, Engineer. This is dedicated to the "subscribers to the Plan" and was clearly intended to be the climax to the series. Watt had already published a Description of $a$ pneumatic apparatus with directions for procuring the factitious airs (Birmingham, Pearson, 1795). This is a technical handbook, with little reference to medical aspects.

Details of the preparation of the gases and of the breathing bags to be used by the patients were given in Considerations Part II, but the account there also shows, not surprisingly, a very humane concern for the patient. Watt promised a portable apparatus, even a "beehive", to place over the head of a weak patient and suggested how to remove the unpleasant smell of the oiled silk breathing-bags. Details concerning these topics appear, as we shall see, in Beddoes' letters. In Part III, Watt was particularly concerned with the safe use of the gases. In 1796, we come to the final form taken by the apparatus for use in a clinic. Since nothing has survived from the Institute at Clifton, Considerations in its various parts is our major source of information about the pneumatic breathing apparatus. Part $\mathrm{V}$ ends with a price list of the apparatus made by Boulton and Watt, packing boxes and carriage to be charged extra. They could supply the various raw materials needed. This was a business enterprise for the firm, in spite of its humanitarian purpose.

The accompanying technical note describes the large apparatus in its final form (see pp. 295-302). In outline, it consisted of a furnace; container for raw materials; means of cooling and washing the gas; and a collecting vessel from which the gas could be conveniently transferred to a storage container. A number of problems had been overcome by providing alternative components suitable for the production of the different gases. The arrangement of the cone "stopper" in the pipe to admit water to

30 Watt junior to Beddoes, 28 December 1794, copy Press Letter Book, Doldowlod.

${ }^{31}$ Black to Watt, 28 July 1796, Robinson and McKie (editors), op. cit., note 4 above, letter 160. 


\section{Dr Thomas Beddoes and James Watt}

the raw material allowed for a controlled flow. The weight of the rising cylinder of the gas-holder was taken by a cord, pulleys, and counterweight; when the counterweight was lifted the cylinder slid down, forcing the gas into a storage holder or direct into a breathing bag. While Watt's contributions to Considerations make clear what the apparatus was to be; the details of modifications as they were made and of consultations over alterations as problems arose are more vividly described in the personal letters, published and unpublished, already mentioned.

Beddoes' letters add some glimpse of the way in which he felt able to be quite open with Watt and to consult him over the most mundane details. They also make clear his anxiety that everything should be as Watt wished. In July 1794, Beddoes had written of being "very glad that [Watt] takes so great an interest in this business." $A$ letter on 21 August 1794 is the first to mention Watt's contributions to the Considerations, Beddoes assuring Watt that he had time to revise because his account of inhaling would come last, and because the slowness of the Bristol printer would help him. He was anxious that the engraving of the plates should please Watt and expressed his willingness to pay well for shaded ones like those in "Cavendish's Phil. Trans. paper" if this style was best suited to illustration of the apparatus. The plates for Watt's pamphlet caused much trouble, being delayed and even going astray when Beddoes' wife undertook to deliver them to Birmingham. (Subsequently, it was discovered that the plates had gone to the wrong Mr Pearson.) The accounts of these minor trials in the letters serve to humanize the technical aspects of Considerations.

Some informal letters from the younger James Watt ${ }^{32}$ suggest that he was responsible for advertising and for publicity. He wrote on 8 November 1794 of having advertisements printed and of the making of the plates, and in December 1794, told Beddoes that the firm had a "large quantity of Machines in hand for which we have received no orders" and, not surprisingly, urged him to recognize that the time had come to promote his plans more vigorously. After all the pneumatic business, Watt added a comment on the sensational treason trial ${ }^{33}$ at the Old Bailey; Hardy had just been acquitted and the argumentative Tooke "enjoys the thoughts of his approaching trial as much as a glutton does the thought of a haunch of Venison." Given this friendly relationship, it was natural that collecting subscriptions and approaching medical men, particularly in Birmingham and Manchester, should have been left to James Watt junior. He also undertook to bring Beddoes' work to the notice of the House of Lords. His first approach, 17 November 1794, was made to Lord Dartmouth to whom he showed "the Machine" and to whom he gave one of the pamphlets and proposals which he hoped "would produce a subscription". In January 1795, he found the Duke of Bedford to be "a very likely man" and advised Beddoes that an approach might be more suitable in the spring when parliamentary business would be less.

Of more lasting value are the descriptions that Beddoes gives of his patients during these two years and of the apparatus that was already in use and being made by the firm of Boulton and Watt even before the Pneumatic Institute opened. The first reference occurred on July 1794, when Beddoes had written asking if Watt knew "one honest

${ }^{32}$ Copy Press Letter Book, Doldowlod.

${ }^{33}$ Thomas Hardy (1752-1832) and the Rev. John Horne Tooke (1736-1812), tried under Treasonable Practices Act of 1795. 


\section{Dorothy A. Stansfield}

workman capable of fabricating complete apparatus, reservoirs and all whom it might be charity to introduce to the public as the manufacturer." The response must have come quickly, for on $7 \mathrm{July,} \mathrm{Beddoes} \mathrm{was} \mathrm{asking} \mathrm{permission} \mathrm{to} \mathrm{announce} \mathrm{that}$ apparatus could be obtained from Boulton and Watt. From July 1794, there are requests from Beddoes for apparatus or parts of apparatus for his patients or for himself. He received an apparatus in August and writes of unpacking it on the 16th. There had been some delay occasioned by bailiffs in the house: "My immediate landlord was in debt to his landlord and others so they seized his furniture. It being inconvenient to reside in an unfurnished house, I was obliged to shift houses." Beddoes' letter to Watt was written from The Mall, Clifton. He had clearly been away from home during the hassle of the bailiff's occupation for Anna Beddoes wrote to her husband from Hope Square describing the incident. ${ }^{34}$ In his enthusiasm Beddoes may have pestered, for by 1 October he had to write apologetically, "I said I would not trouble you about apparatus again."

The first of the "pneumatic patients" was Mr Knight of Painswick, thirty miles north-east of Bristol, who on 3 September 1794 had already asked for an apparatus. Beddoes wrote that he would take it to him, and appears to have done so the next day, for he wrote from Painswick asking for an apparatus for himself. Beddoes continued to treat Mr Knight throughout September, and on 1 October a letter reported that he wished to try "unrespirable airs" for a deep-seated ulcer of the pelvis. Meanwhile, another patient comes into the accounts, a Mr Capper who was being given hydrogen and whose experience is described in Part I of Considerations, 1795. On 15 September, Beddoes referred to Capper being "here"-presumably in Clifton-and to efforts to prevent the gas being nauseating. By the 18th, he had some success, for Capper was breathing "unmixed hydrogen" and finding it "useful". This letter tells of Beddoes going to Painswick for two days, Thursday to Saturday, and when he next saw Capper on 27 September, he gave him "fixed air mixed with $4 / 5$ or $5 / 6$ atmospheric air"-but he complained that, as Capper would not keep to his diet, it was difficult to see how well airs were succeeding. Capper appears to have had few doubts, Beddoes' treatment seemed to him to be succeeding. On 1 October the report was that after taking hydrocarbonate he "became cool, slept all night, coughed scarce at all and expect ${ }^{d}$ not more than $1 / 2$ the quantity of the preceding night. He is languid however and I think we must join some tonic or gently stimulating medicine." This was when Beddoes had to be apologetic about apparatus, for Capper wanted "that of which he has the pot and capital compleated-the orifice of the horizontal tube of the capital is $13 / 8$ inch diameter-he wishes for a conducting pipe, refrigeratory, hydraulic bellows the same size as mine that is I believe a cubic foot." Capper went to Sidmouth ${ }^{35}$ where he intended "to carry all this with him", but neither of him nor of Mr Knight do we hear any more. On 5 March, Beddoes was reporting successful treatment of paralytic

\footnotetext{
${ }^{34}$ Anna Beddoes to Thomas Beddoes, 20 July 1794, Bodleian Library MS Dept. C 134-137, papers of Thomas Beddoes.

${ }^{35}$ Sidmouth was regarded as an excellent place for invalids. In the 1790 s, it was still a fishing village and perhaps somewhat livelier than it later became. In 1849, the Tourists' and visitors' handbook to Sidmouth and its neighbourhood was hard to put to it to conceal its dullness, but quoted an account of its beneficial climate, which must have been what commended it to Beddoes' patients.
} 


\section{Dr Thomas Beddoes and James Watt}

patients and ordering an apparatus and oxygen for a patient at Clifton, a Mr Gladwell. This patient gave him trouble of another kind. He was "rich but avaricious", and Beddoes' problem was to collect payment for the apparatus. At this time, Beddoes was trying out gases-principally oxygen and hydrogen-in his practice in Bristol, for in January 1796 he had "two other patients breathing". These activities obviously became well known and caused alarm: "The day I left Clifton I had enquired out a typhoid small poxed child. The case being quite desperate I was going to try oxygene-but by the time I could get the boy an air holder 5 or 6 beldames had appeared. They grew frantic on seeing the air holder as if it had been a coffin. So I was drove [?] and thought myself happy to escape mobbing."

The letter of 18 September 1794, besides discussing Capper's treatment, gives an account of Dr Ewart of Bath visiting Beddoes on a Sunday. They discussed Ewart's use of carbon dioxide to treat cancer. At this stage, Beddoes believed that for consumption, carbon dioxide was most succesful in the early stages before the ulcers had spread.

Writing from near Ludlow in January 1796, Beddoes mentions a Mr Sheppard who had "had a small apparatus-Hde [?hydrogen] has always taken off the asthmatic strictures and made the respiratory process quite free. When he has taken fresh cold it weakened and depressed him. I had advised to take HDE \& ox mixed when he had no cough or tightness and indeed to try one by itself. This last produced strictures as I have seen it in asthma. I have now advised him to try hydrogen." Beddoes proposed, at Watt's suggestion, to treat Mrs Sheppard with desulphurated hydrogen, presumably hydrogen prepared by dissolving zinc or iron in sulphuric acid, freed from acid spray by passage through alkali. Also described in the Ludlow letter is "R.W.", a patient in an advanced state of "dropsy of the debauched", whose "oedematous tumours" Beddoes was thinking of treating first with digitalis, small doses of opium, warm bathing, and then, if these did not succeed, with oxygen "if I can procure it". We know that another apparatus was in use at Exmouth, for Watt reported that Lady Isabella Douglas returned one from there.

More detailed accounts are given of two patients: Lord Daer ${ }^{36}$ and Mrs Kerr. Lord Daer was one of the circle of Whig aristocrats who at first welcomed changes in France and hoped these would lead to worldwide reform. With the Duchess of Devonshire endeavouring to win Sir Joseph Banks's support and with Daer as his patient, it is clear that Beddoes had some friends outside the circle of industrialists and scientists. Lord Daer went to Bristol for treatment and on 14 October 1794, Beddoes wrote of his being in "a confirmed consumption and planning to go to Lisbon". In another October letter giving news of good sales of Considerations, Beddoes expressed his regret that he was unable to persuade Lord Daer to have his room filled with fumes of "effervescing mixture with vinegar". He had tried some airs but in Beddoes' opinion was too occupied with trifles and perplexed by contrary opinions. Beddoes was convinced that rooms filled with airs were superior to the breathing apparatus, and he later used this treatment for Tom Wedgwood. By 1 January 1795, Lord Daer's apparatus had been found in Bristol. "I verily believe", Beddoes wrote, "Lord Daer's app is arrived at

\footnotetext{
${ }^{36}$ Lord Daer (1763-94): Basil William Douglas, eldest son of the Earl of Selkirk. For his activities in the radical movement of 1791 onwards, see A. Goodwin, The friends of liberty, London, Hutchinson, 1979, pp. 197, 209.
} 


\section{Dorothy A. Stansfield}

Bristol ... my operator discovered it by accident looking for something else"-a true Beddoes incident. Beddoes paid for this machine and for Mr Gladwell's on 8 January when he wrote declining James Watt junior's invitation to go to London. He explained that he had only time for a brief visit to Birmingham, for he needed to be in Bristol to attend his patients. Between his first inquiry and this report, Lord Daer had wavered between Beddoes' treatment and going to Lisbon and on 24 October 1794 had been persuaded to breathe fixed air which he "bore astonishingly". Whether the apparatus sent in December 1794 broke or needed improvement is not clear, but on 20 May 1795 Beddoes was reporting that it was a failure and admitted to a mood of depression, though he put this down to the political scene. However, by the end of the letter he was being cheered by news of two "clear cures". In July, we hear of another machine having been delayed - occasioning in Beddoes' view the loss of a sale. Lord Daer seems to have been a difficult patient, refusing to carry on with his treatment. Muddles with the apparatus and over payment combined with Lord Daer's reluctance to take advice had made the episode a disappointment. James Watt junior's view was that "if men will not follow advice they must take the consequences".

The patient whose treatment is described in the greatest detail is Mrs Kerr, and this is an interesting history showing clearly how Beddoes did not use airs to the exclusion of all other remedies. It seems worth quoting at some length from the letters concerning Mrs Kerr for the vivid impression they give of Beddoes' combination of technical skill with sympathy for his patients. On 5 October 1795, Beddoes was in touch with $\mathrm{Mr} \mathrm{Kerr}$ concerning oxygen, and by 14 November, he was proposing to take Kerr to call on Watt. The object was to find means of "some form of motion" similar to equitation which, he considered, was of certain use to consumptives. Watt devised a machine for this "mechanical medicine" which Beddoes got made; ${ }^{37}$ by Christmas, a frame for swinging had been erected and the treatment found beneficial. Beddoes was very hopeful that it would do good, being "the most simple contrivance as well as the most agreeable yet devised." A letter written in April 1794 by Dr Darwin, who had suggested a form of rotating couch for Jessie Watt, makes this swinging clearer: "If swinging could be perform' $d$ by being placed on a chair, and whirl'd circularly and horizontally, so as to induce sea-sickness once or twice a day, even without vomitting by it, it might like real sea-sickness promote absorption - which is the means of curing self-spreading ulcers." ${ }^{38}$ Beddoes told Watt: "I am trying the inhalation of powders. This is very practicable they do not excite anything, if the dust comes in moderate volume...." In January, Mrs Kerr seemed well, for on 1 January Beddoes had altered the diameter of the pulleys and described how "Mrs. Kerr and myself had a glow when quickly turned. I wished to make Mrs. Kerr glow about 3 o'clock thinking it might keep off, by anticipating, the flushings at 5 or 6 . Now the same time and velocity did not produce the same effect in Mrs. Kerr". Beddoes was giving careful attention to this swinging apparatus since he believed that "when regulated by a little experience this machine will be of considerable use in medicine." As well as using the "swinging couch", Beddoes had given her "yellow bark" (Cinchona Calisaya), and on 12 January, he wrote to Watt a long account of the swinging which, besides the technical details,

${ }^{37}$ Robinson and McKie (editors), op. cit., note 4 above, letter 168.

${ }^{38}$ King-Hele (editor), op. cit., note 5 above, p. 247. 


\title{
Dr Thomas Beddoes and James Watt
}

reveals the attention Beddoes gave his patient and the considerable nursing care involved:

\begin{abstract}
When Mrs Kerr \& I felt a glow at the head \& feet, the revolutions were near or above 100 per minute. At this rate we never felt any vertigo, but when the motion was changed to slower, we did, the eyes being shut. When Mrs. Kerr thought she slept better, the motion I know was slow, but I know not how slow - the nurse turning in the night - certainly not above 25 in a minute-She has still been free from flushing, except one evening, for a month past-You ask what alterations we have made - they were alterations for local adaptation. But there is an alteration which I thought wd. be an improvement, viz, to make the side pieces perpend ${ }^{\mathrm{T}}$ for the sake of more swinging - The pulleys are still as by your drg-I had spoken for a small pulley over the bed \& thought when I wrote it was made and added, but it has not been \& I believe will not be as the slow revolution is most agreeable to Mrs. Kerr and she has long been with ${ }^{t}$ those chills for which I wish a rapid motion. I sh ${ }^{d}$ think if the heart were in the centre of motion, it $w^{d}$ be advantageous - It might too in some cases, if the head were. I have no objection to your repeating in print any thing I have written on this subject. It amounts to this-superficial glow on rapid motion-no constant change in the frequency of the pulse, (I say constant, for once or twice we thought she did observe a reduction) but pulse rendered more full-vertigo when the motion becomes slow from rapid; viz, 20 revolutions from +100 . No unpleasant internal feeling, when rapid, $\&$ indeed you are hardly, if at all, sensible you are revolving, if your eyes are shut.-A much reduced phthisical lady thought she slept better when the couch went slow she certainly did sleep much [word missing] while it was going, for her mother lay in the same room where the nurse turned to supervise her-The evening heats \& flushes did certainly go away for weeks after this plan was entered upon and still keep away-and no known change in diet or medicine besides-but queri if owing to this.... The vertigo arising from the change from quick to slow I cannot say is violent. But the whole sensation is to me highly disagreeable-I sh ${ }^{d}$ have written sooner, if I had not been so much from home. Mrs. Kerr is extremely weak — \& gets weaker, but has no distressing feelings. Even her cough does not hurt-no chills, no sweats, hardly any flushing. It is the slowest decay I have seen.
\end{abstract}

The slow decline continued for another six months. In July 1796, Mrs Kerr was again advised to try oxygen, but the failure of their efforts was clear and Beddoes was most concerned for her peace of mind. "Poor Mrs. Kerr is so bent on going that I believe it is a duty of humanity to indulge her. She would die in sorrow here-hope may prolong her life and make it easy while it lasts but to go north is a fearful undertaking at this time of year." This sad account of Mrs Kerr-the doctor trying the effects of the rotating couch for himself; the mother watching in the night; the trials of oxygen, and in the final letter the prescription of a "mineral solution" of arsenic, illuminates the collaboration of Beddoes and Watt. Beddoes as a doctor and Watt as a parent remembering the death of his daughter and watching fearfully the health of his son, Gregory, were desperate for success.

Beddoes and Erasmus Darwin were by no means the first to consider swinging as a less drastic method of inducing nausea than the more common emetics. In 1787, J. Carmichael Smyth FRS (physician to the king) wrote almost lyrically of this cure:

To conclude: as the sedative power of motion, to which we have ascribed the efficacy of sailing and swinging, is a principle hitherto unknown, I have been at some pains fully to establish it; and am convinced in my own mind, that when conducted with skill and integrity, it will not only be found useful in the cure of pulmonary complaints, but may probably be employed with advantage in a variety of other cases, especially when what is suggested shall have been improved by the ingenuity \& experience of future ages. ${ }^{39}$

Smyth had had his patients taken into the garden of the Middlesex Hospital and "put into the swing"; he measured success by the lowering of the pulse rate. This apparatus

39 J. Carmichael Smyth, An account of swinging, 1787. 


\section{Dorothy A. Stansfield}

made the benefits of swinging available to those who could not afford a sea voyage: "The man who, like the oak, is tied down to the soil which gave him birth, may as easily obtain it, as he who can change his situation at pleasure, and become a citizen of any country."

The striking difference between the London doctor and Beddoes is that once having prescribed swinging, Smyth left his patients to the care of the hospital apothecary, $\mathbf{M r}$ Bosse, who was also entrusted with making the observations. Nowhere in his pamphlet of some sixty pages does Smyth give any description of the swing, of the means of setting it in motion, or of its speed. ${ }^{40}$

Beddoes' interest in medical apparatus and his mechanical bent come out clearly in these letters and this was an interest he never lost. Letters to Watt, written much later, discuss the desirability and possibility of a mechanical leech to bleed a patient and inquire whether there might be some way of constructing a device to measure the uneven growth of different parts of the body at various periods. The details about the breathing apparatus in these letters show Beddoes able to enter into the technicalities of its construction and of the production of the gases. Though clearly it was Watt's greater experience and mechanical genius that finally produced a practical and convenient apparatus, the matter was by no means completely handed over to him. In the summer of 1794, Beddoes described his own experiences and put forward his own suggestions. Early in the discussions, on 26 June, he expressed his preference for a room in which the patient could be confined while a gas was breathed. He explained that Dr Darwin disliked the method whereby the patient breathed through a tube in the mouth, the objection being that he would breathe through the nose at the same time. The first consultation with Watt was over the bags which held a convenient amount of gas for the patient to breathe and, not surprisingly, so soon after Jessie Watt's death, the concern was for the comfort of the patient. Beddoes, on $14 \mathrm{June}$, sent a drawing of these bags. Watt must have come back quickly with the suggestion of using charcoal to remove the unpleasant smell of the oiled silk for, on 26 June, Beddoes replied that he liked the "dry way" of using it. The problem remained under discussion, and on 23 September, Beddoes was suggesting the possibility of a varnish of caoutchouc being better than charcoal. In Considerations Part II (September 30 1794) charcoal is advised. This is described in detail in Watt's 1795 booklet:

To free oiled silk from its disagreeable smell, cut it into pieces of the size wanted for the bags and provide a smooth table somewhat larger than the pieces of silk, and a flat board of the same size as the table. Take charcoal fresh burnt in an open fire until it is free from smoke, extinguish it by shutting it up in a clean vessel, and reduce it to a powder. Sift this powder over the table to the thickness of a quarter of an inch or more, spread a piece of silk upon it, and sift upon that again another layer of your charcoal dust, and thus proceed alternating the layers of silk \& charcoal, until the whole of your silk is deposited; then lay your moveable board upon the top of all, and leave the whole undisturbed for four or five days. If upon removing the charcoal dust, the silk has not lost its smell entirely, repeat the process. The charcoal dust is to be swept off the silk, and the silk to be washed upon a table with a wet sponge until it is clean.

\footnotetext{
${ }^{40}$ It is perhaps worth noting that "whirling around" was a method sometimes used with mentally ill patients. It was tried at The Retreat, but William Tuke considered the treatment cruel and discontinued its use. Mary R. Glover, The Retreat, York. An early Quaker experiment in the treatment of mental illness, York, Ebor Press, 1984.
} 


\section{Dr Thomas Beddoes and James Watt}

In the same letter Beddoes put forward a suggestion that the tube might be coated with lime to save it from corrosion by vitriolic acid. He had ideas about the most convenient form of the vessel for heating nitre or manganese; about the width of the neck of the "pot", wondering whether it should be wider; about the position of the pipe and about the flexible tube. Possibly it was a suggestion from Beddoes that led to Watt's note in Part V that the apparatus might be simplified by "laying aside the hydraulic bellows \& refrigeratory, \& conveying the air directly from the fire tube, wherein it is generated, to the air-holder [which would be made possible by] making the lower pipe of the air-holder inclined at an angle of $45^{\circ}, \&$ of such length that the lower edge of its mouth shall be a little higher than the upper edge of the inner opening by which it communicates with the air holder."

Beddoes worked on methods of making the gases and first mentioned oxygen in July 1794. In August, he told Watt that he had found Argand's lamp was not hot enough for his purpose. At the same time, in Birmingham, Watt also had been trying out means of producing gases. "Inflammable air" he produced from charcoal and water, and carbon dioxide by dropping water on red-hot chalk. The effects of breathing inflammable air-water gas in this case-puzzled Watt, as this produced vertigo and loss of consciousness. Eventually, in January 1796, he was successful in producing hydrogen that could be breathed without these ill effects and identified their cause as sulphur impurities. In September 1794, Beddoes wrote to Watt that he was consulting Reynolds about Exeter manganese and by the end of the month both Beddoes and Watt were supplied by him. This was help which William Reynolds was well placed to offer. He was both geologically and practically concerned in the discovery of supplies of minerals and needed manganese as a raw material in the Coalbrookdale iron works, in particular for the experiments to produce high-quality iron. ${ }^{41} \mathrm{~A}$ high temperature is needed to decompose manganese dioxide, the reason why the Argand lamp was not satisfactory. Both Watt and Beddoes continued to work on the problem of producing oxygen free from noxious impurities. Watt found that Beddoes' suggestion of a lime-coated tube nearly succeeded, and Beddoes produced a satisfactory result by using vitriolic acid on Exeter manganese. Beddoes, we see from Considerations, felt that this was superior to the Mendip manganese that Watt had been using, but in Watt's view, "the purity of the dephlogisticated air which you [i.e. Beddoes] obtain" was at least in part due to Beddoes' "means of disengagement".

As well as oxygen, Beddoes and Watt were producing hydrogen. Watt dissolved either iron or zinc in sulphuric acid and called his airs Martial and Zincic inflammable air; Beddoes, in connexion with Capper's treatment, used zinc and, with his patient's nausea in mind, wrote of transmitting the gas through alkali. This would have produced the pure ("unmixed") hydrogen which proved less unpleasant. We can follow how the possibilities opened up by the new chemistry of gases were explored in these parallel experiments by Watt and Beddoes.

These technical discussions led to the production of the apparatus already described, which we see was on sale by the firm of Boulton and Watt before the end of 1794. The firm must have anticipated a demand, for James Watt junior wrote from Soho in the letter referred to earlier (28 December 1794):

${ }^{41}$ See note 18 above. 


\title{
Dorothy A. Stansfield
}

\begin{abstract}
We have now a large quantity of machines in hand, for which we receive no orders excepting those abovementioned \& two or three for Birm $^{\mathrm{m}}$. I shall advertize in the Monthly Review that we have them for sale and shall endeavour to get one fixed up somewhere in London for the public to see it. Can you point out any convenient place. I shall go to London the beginning or middle of next month-Will you meet me there?? I think it is now time you should be coming out with your new proposals, as I do not see that we are likely to do more in the way of procuring money until we have authenticated cases of Cures.
\end{abstract}

The activities of Boulton and Watt prepared the way for the Pneumatic Institute; Considerations Part II, when it appeared with its clear and well-illustrated description, was the culmination of Watt's work, in which Beddoes took a not inconsiderable share. This was indeed the essential step making possible Beddoes' trial of pneumatic medicine, and these letters give some glimpse of Beddoes' own involvement.

There are letters from other medical men tied up by Watt in this "pneumatic correspondence" and, since they round out our impression of his activity in the matter, they may be briefly described here. Erasmus Darwin first wrote in 1794 principally about Jessie Watt's illness, but from November 1794, he was directly concerned with the progress of Beddoes' plan. He recognized its importance as proving the means of making possible the many experiments that would be needed for a convincing test of pneumatic medicine. In April 1795, Darwin had a lady coming to Derby to breathe oxygen and was recommending the apparatus to the infirmaries at Nottingham and Shrewsbury. Another apparatus for making "oxygene gas" was taken to Cullompton in Devonshire by Darwin's patient, Thomas Babington. It seems that Babington was already using a breathing apparatus at his home in Leicestershire, for Darwin warned Watt that he did not need a tube, just the pot. The Birmingham surgeon-apothecary, James Barr, who attended Watt's family, successfully used an apparatus for his patient Gilbert Hamilton, in Glasgow, in September 1795, just too late for his report to be offered to Beddoes for inclusion in Considerations. The most interesting references to breathing apparatus came from Dr Thomas Henry (1734-1816) of Manchester. Writing in December 1794 for an apparatus for himself, he told Watt how an apothecary at the Manchester Infirmary had nearly had an explosion when trying out the apparatus. This led him to urge James Watt to put a caution in the new edition; whether on Dr Henry's advice or not, such a warning was given: "The process for obtaining inflammable air should not be conducted by candle light, otherwise the approach of the candle to the stream of air may occasion dangerous explosions. For the same reason, when a patient is inhaling the air by candlelight, the candle should be kept as distant as possible." Dr Henry's younger son, William (1774-1835) wrote to the Manchester paper to promote pneumatic medicine and Dr Henry continued both to experiment and (with some difficulty, as times were hard) to collect subscriptions. His older son, Thomas, reported from Philadelphia that Joseph Priestley was repeating the experiments. When, seven months later, Dr Henry acknowledged the receipt of an apparatus for this son, he had to explain that Tom was on a voyage to Bombay and China as a ship's surgeon and promised that the apparatus would be sent to Philadelphia to wait for him in the care of a friend named Griffiths. This letter proves that Beddoes' work was known in Pennsylvania at a very early stage and in a direct way. 


\title{
Dr Thomas Beddoes and James Watt
}

Watt also had letters from two men already exploring the theory and possibilities of pneumatic medicine. There are four from London, from Dr Thornton at his house in Great Russell Street. His letters have an authoritative tone as he enters into the theory of pneumatic medicine. In his view, "the airs did much notwithstanding the errors of the Brunonian system" and after referring to the experiments of Dr Girtanner and Beddoes, he promised Watt that he himself would construct a room such as Watt described at Bennet Street, St James's. There he proposed to make a "cautious trial of different atmospheres" and he thought much might be done "by conveying different substances to the lungs". Both Beddoes and Watt felt that Thornton was determined to keep his position as the leading exponent of pneumatic medicine in London. Thornton's cool, measured tone makes a striking contrast to Beddoes' own enthusiasm. The other doctor with a reputation in pneumatic medicine whose letter survives in this collection was Dr Ewart of Bath. Watt, knowing that he was about to publish an account of his work, was anxious that the publication of Considerations should not make difficulties for him. On 5 October 1794, Ewart assured Watt that he was happy, saying in a very generous manner that he was already in touch with Beddoes about the overlapping of their work. Ewart's tribute to the importance of Watt's interest in "the application of airs in diseases" makes very clear the style of the medical world in the late eighteenth century and the conservatism among physicians that made Watt's support valuable to Beddoes. Ewart concluded his letter to Watt,

\begin{abstract}
You engage in the subject with fewer prejudices and are likely to see more clearly and to report more faithfully the result of your experiments than most physicians are. Your character and pursuits likewise shield you from the unfair imputations cast at professional men who aim at improving their defective science; and your example will [?encourage] many from their lethargy who without it would have gone on in their jogtrot routine, without either looking behind or before them.... I have long been of opinion that any great revolution to perfect the medical art was never to be expected from physicians.
\end{abstract}

Beddoes' appreciation of the qualities which Ewart so well described is clearly seen in these letters. They change in tone from respectful formality to enthusiastic confidence that he could bring all his hopes and problems in detail to Watt's attention. While we understand Beddoes' enthusiasm, we cannot but admire Watt's patience and the generosity and faith with which he continued his assistance.

\section{PART II: A TECHNICAL NOTE ON JAMES WATT'S DESIGN OF THE BREATHING APPARATUS}

The second edition (1795) of Considerations contains, in Part II by James Watt, a full description of the apparatus for making gases as he had designed it, with detailed instructions for setting it up and using it to make the different gases. This includes a set of professionally-drawn illustrations of the large apparatus as made and sold by the firm of Boulton and Watt. The description and illustrations would show a purchaser exactly what he would receive or-as Watt himself says - they would enable a man to have one made locally. The drawings remind us that the firm must have had a substantial drawing office, accustomed to producing illustrations for sales literature or patent applications as well as finished working drawings for production purposes. 


\section{R. G. Stansfield}

Four plates, each including several separate figures, show us a set of apparatus, ergonomically sound for convenience in use and well production-engineered for manufacture, comprising interchangeable and replaceable components to be put together in a variety of combinations as appropriate for the gas to be made. Standard cone-joints are used for pipes connecting the components and for other demountable joints. Plate 1 is a sales drawing of the basic apparatus. Plate 2 shows in cross-section details of various components shown in plate 1 . Watt says that plate 3 shows apparatus improved in some respects from that of plates 1 and 2. Its figures provide working drawings, with a scale of feet and inches.

The basic apparatus is shown in plate 1, fig. 1. The three plates and Watt's description make clear its construction and use. The materials to produce the gas react in an "Alembic or Pot" (Watt's names), a bulb of soft cast-iron 6 inches in diameter standing within a circular brick-lined solid-fuel furnace, 18 inches over-all diameter. A wrought-iron "Conducting Pipe" connects the retort (the "Alembic") to a "Refrigeratory" where the gas is cooled by passing over the surface of water and, if necessary, scrubbed of impurities. The cooler is plugged directly into the inlet of a "Hydraulic Bellows" to receive and measure the air, a water-sealed rising gasometer with the rising cylinder counterpoised by a weight-and-pulley system so that gas is drawn into the gasometer. The gas "is then expelled into the air-holder or bag through the discharging pipe $\mathrm{Q}$ by lifting up the counterpoise $\mathrm{L}$, and allowing the inner vessel to descend of its own weight." The quantity of gas is measured by the movement of the rising cylinder. Watt noted that the gasometer would hold $1695 \mathrm{cu}$. inches, or rather less than a cubic foot of gas. (As a guide to quantities, we may remember that "at normal temperature and pressure" $1 \mathrm{cu}$. ft. of oxygen weighs approximately $40 \mathrm{gm}$. or $1.4 \mathrm{oz}$.; of nitrous oxide $56 \mathrm{gm}$. or $2 \mathrm{oz}$.) The figure shows the alembic fitted with two other components. One is a water-feed pipe; this ends in a needle-valve, adjusted by a disc at the top of a screw-threaded length of the valve needle-rod. This screws through a bar across the top of a bowl to hold a supply of water; from this bowl the valve-rod runs down inside the water-feed pipe itself to the valve-seating at the bottom. Turning the disc, which has a milled edge, adjusts the flow of water or cuts it off. The pipe is socketed into the second component, itself socketed into the "Capital" of the alembic, a pipe reaching almost to the bottom of the charge in the alembic.

An alternative reaction-vessel for generating gas, a cast-iron "Fire Tube" which Watt found more suitable than the alembic in many cases, is shown in vertical cross-section in fig. 3 of plate 1 . It is set horizontally through the middle of a solid-fuel stove of different design. The figure shows additionally a horizontal cross-section of the right-angled plug-tube to take the gas to the conducting pipe leading to the gasometer (see also plate 3, figs. 2 and 3). The plug closing the other end of the fire tube is shown with a socket holding the water-feed pipe component; the water becomes steam before reaching the heated charge in the fire-tube.

Three components not included in the previous plates are shown on plate 3. Here figs. 1 and 2 (elevation and plan respectively) show on the extreme left, connected by a pipe to the exit port of the gasometer, the "Air-Holder", a portable gasholder made - like the gasometer — of japanned tin-plate. It is designed to deliver a measured volume of gas when that volume of water is poured (through a funnel) into a pipe set in 
the top and open just above the bottom of the gasholder. A port low in the side of the gasholder allows water to run out when gas is drawn in through the gas entry- and delivery-port. We can appreciate the space needed for the apparatus when we notice that these figures show a set of components $9 \frac{1}{2} \mathrm{ft}$. long as they are connected.

Fig. 4, plate 3, shows another vessel for generating gas: a retort, presumably of glass and with tubule and stopper, of volume about 1 litre, set on a sand-bath on a solid fuel stove of yet another design, this time with chimney. (Watt noted that the other stoves were without this, because a chimney made the fire harder to control). Figure 5 on this plate, to a smaller scale and a pencil sketch of different style, shows a tube drawing gas from the heart of a fire in an open brazier; this tube is connected to a simple cooling-tube passing through a trough of water.

The care taken over detail in the design of the apparatus is shown by, for example, the carrying handles on the side of the portable gasholder (plate 3 ) and also of the stove shown in figs. 1 and 2 of plate 1 . The cover of this stove is shown as made in three segments, each fitted with a lifting-ring, leaving a small sector open for the escape of burnt gases. In figs. 1 and 2 of plate 3 , the design of the stove for heating the fire tube appears to have been refined from the corresponding design shown in fig. 3 of plate 1; noteworthy is the ash-door (lower right in the figure) and the design of the slide controlling the air-intake to the fire, arranged so that the handle would be easy to grasp and not become too hot. Watt says that the size of the gasholder was determined because, if larger, it would have been too heavy to carry when full of water. All parts of the apparatus can be dismounted for easy cleaning; for example, we see from plate 1 that the gasometer is designed so that the superstructure carrying the pulleys, rising cylinder and counterpoise simply lifts out of two tapered sockets on the fixed cylinder.

Again, Watt mentions that the air-holder was made in two halves, for convenience of japanning the inside, "which are joined together in the middle of the vessel, by a cement composed of bee's-wax and one fourth of its weight of rosin, applied hot." Warmed before a fire, the vessel may be taken apart, cleaned and reassembled. More important, the apparatus was manufactured in two sizes. As well as the "large apparatus" shown in the plates, with a gasometer holding 1695 cubic inches of gas, "or rather less than a cubic foot", the smaller size had a gasometer holding $570 \mathrm{cu}$. ins., about one-third of a cubic foot. Other components were made appropriately smaller. Watt is careful to point out that larger- and smaller-size components could be interconnected and used together.

The completeness of the description of the apparatus and of the procedures for using it, together with the extensive attention to detail, confirm not only that Watt was deeply interested in the whole matter, but also suggest strongly that he spent much time over preparing and experimenting with the use of gases and thoroughly enjoyed carrying out himself at least the central processes, not leaving them to laboratory assistants under his supervision. So he gives much incidental information of real interest. Lutes were used to make airtight the joints in the apparatus. "Fire-lute" is specified as made of "Cornish porcelaine clay, or slacked and finely sifted lime, mixed to the thickness of paint, with a solution of two ounces of borax in a pint of hot water." By contrast, "Cold lute" is "a paste of dough made of about equal parts of wheat flour and porcelaine clay, or common whiting", although "A slip of oiled silk does very well 


\section{R. G. Stansfield}

without any lute." "Fat lute" "is made of finely sifted slaked lime and drying linseed oil, wrought into a pretty stiff paste, and applied to the hot joints with a small trowel." Watt considers fuel for the stoves: "The proper fuel is good coaks or cinders of pit coal, which ought not to be of the heavy sort, nor too small, as in either case you would have a dull fire." Charcoal "would answer very well", but the quantity required would be too expensive. He comments on the use of corks for closing the various gas and water inlet- and outlet-ports. Corks are better than stop-cocks, both because they are more airtight and because the latter are made of "a material, the rust of which is very poisonous, being a composition of copper, lead, tin, arsenic, and antimony, or whatever other metals the ores may happen to contain." In Watt's paper there are many reminders of the problems arising because he had to use materials which were far from pure; problems because the impurities - sulphur in particular-often appeared to produce noxious contaminations of the gases desired, and problems because he could have only very limited knowledge of the nature and quantity of impurity in any material. There was practical difficulty, too, because of the corrosive nature of the gases or the acid spray carried over by them, e.g. in hydrogen prepared from a metal dissolved in sulphuric acid. Regarding the gas-holders, Watt comments that japanned tin-plate is particularly resistant, "even to aqua fortis". Bags of linen or, usually and better, oiled silk were used to hold gases for patients to breathe or even for storage; Watt comments that "green oiled silk should be avoided, as it is stained by means of verdigris, which rots it; the yellowish silk is the best." The main problem with bags was to make the seams airtight; various varnishes to do this are mentioned, none really satisfactory. The last plate in the paper, plate 5 (not reproduced here), is a pencil sketch of a breathing bag attached to a rigid, cubical box whose open top carries a fabric sleeve to serve as a mouthpiece for the person breathing the gas from the bag. Non-return flap-valves in the bottom and a side of the box allow gas from the bag to be breathed in, and the exhaled breath to escape outside.

Reading the paper, one senses that the part of the design of the apparatus in which Watt took most pride was the "Refrigeratory" shown in plate 1 and detailed in plate 2. Its purpose is to cool hot gas from the stove, to allow the gas to deposit fumes or spray carried over and also excess water-vapour, and when appropriate to "scrub" the gas of unwanted constituents, e.g. using a suspension of lime to remove carbon dioxide. The ingenuity lies in the 5-turn spiral gas-channel, shown in vertical cross-section and also viewed from below, in fig. 3 of plate 2 . This channel is closed above by being fastened to the inside of a shallow inverted dish; gas cannot escape downwards because the walls of this dish and of the spiral dip under the surface of water or other liquid contained in the vessel shown in fig. 2 of plate 2 . Gas enters the outside of the spiral by the pipe shown on the left of the upper half of fig. 3 , circulates round the spiral and emerges through a rising tube from the centre of the spiral leading to the exit tube shown to the right of the upper part of fig. 3. Flowing through the spiral, the gas passes over the open surface of the water or other liquid into which the walls of the spiral dip, so that the liquid can take up impurities. Watt describes how a stirrer can be provided to agitate the liquid so as continually to expose fresh surface to the gas; this stirrer consists of a rotating paddle immediately below the spiral, the paddle being fastened to and turned by a vertical rod passing down the vertical tube shown in the centre of the upper part of fig. 


\section{Dr Thomas Beedoes and James Watt}

3. Unfortunately, the draughtsman who finally prepared this figure appears not to have appreciated the subtlety of Watt's idea and to have run into one this tube-which is not open to the gas-channel through the spiral-and the rising gas-outlet tube; the two tubes are, however, shown separate, side by side, in the lower part of this figure. (The same error was made in drawing plate 1, fig. 1.) Fig. 2 shows the vessel which holds the cooling and absorbing water or other liquid. On the left there is a funnel and tube to lead added, cold liquid to the bottom of the vessel so that spent and warmed liquid flows out through the port high on the right side. A second port, below this one at the level of the bottom, allows the vessel to be emptied completely. The design of this refrigeratory once more shows Watt's attention to practical detail, guided by theoretical appreciation of what is appropriate. His fascination with ways of solving some problem appears in plate 4 (not reproduced here), which contains four illustrations in the style of an engineer's rough sketch of an idea, not detailed for actual making. One of these shows a box through which gas is passed; it is half-filled with liquid, and this liquid is to be splashed about inside the box by turning an external handle which rotates a vertical wheel, with many small paddles around its edge, half-immersed in the liquid-thus providing a "scrubbing" of the gas more thorough than that produced by the spiral refrigeratory described above. With such ingenuity available to him, it is understandable that Watt's account seems almost regretful when he recognizes that for some purposes a simple straight cooling tube-as in plate 3 , fig. 5 -is perfectly adequate to meet the need. 


\section{R. G. Stansfield}

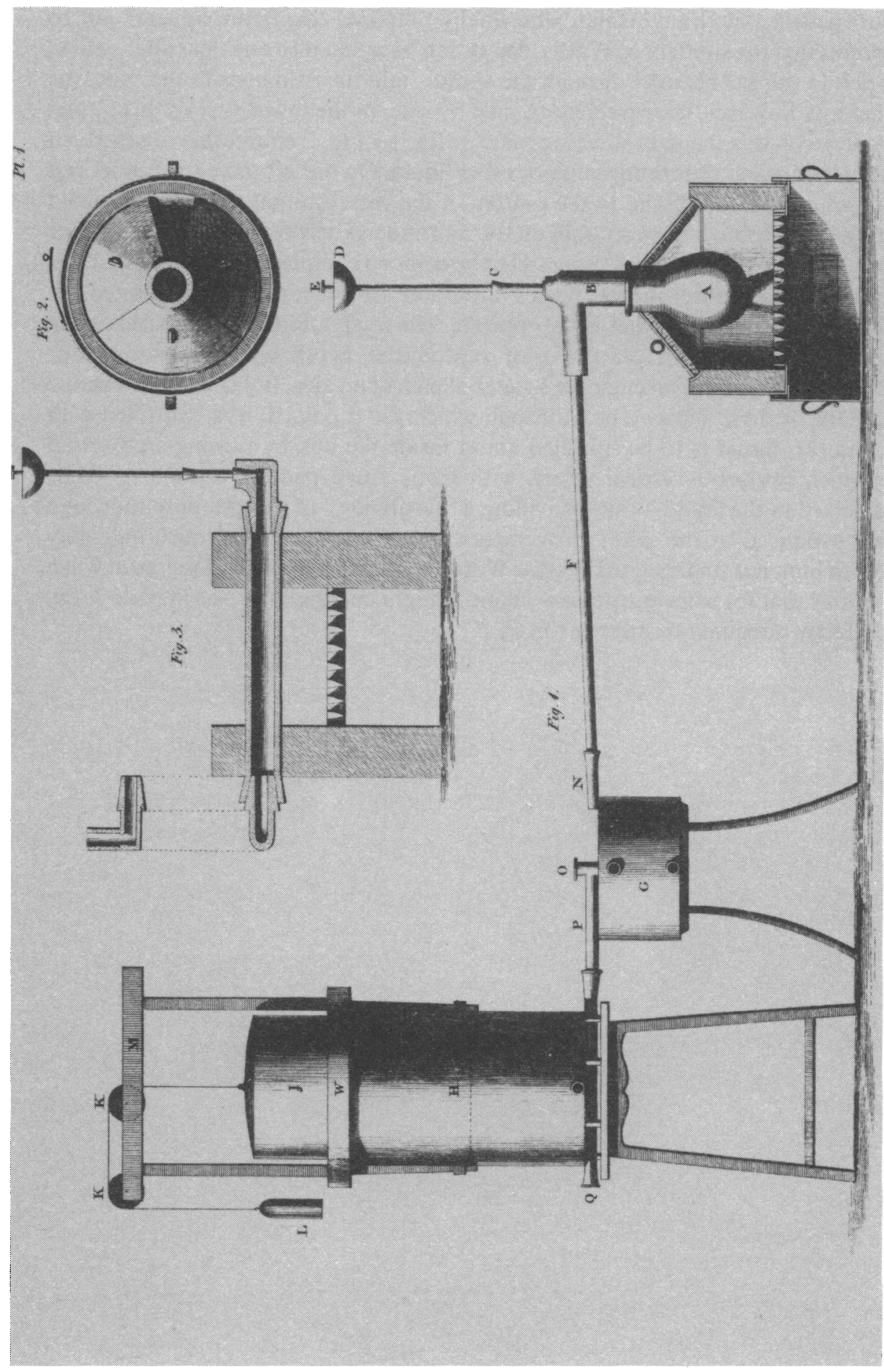

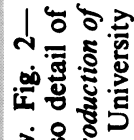

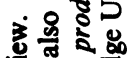
'立究 을 응 . 乌ั ह \& 要 욜 \%을 矛㐘 象 응 ठ8 ० है

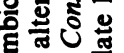
음 \% - 结焉 영 西要 Di 记 的 元 영은 중 오 통든 82 동

- 8 है

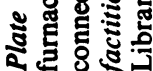



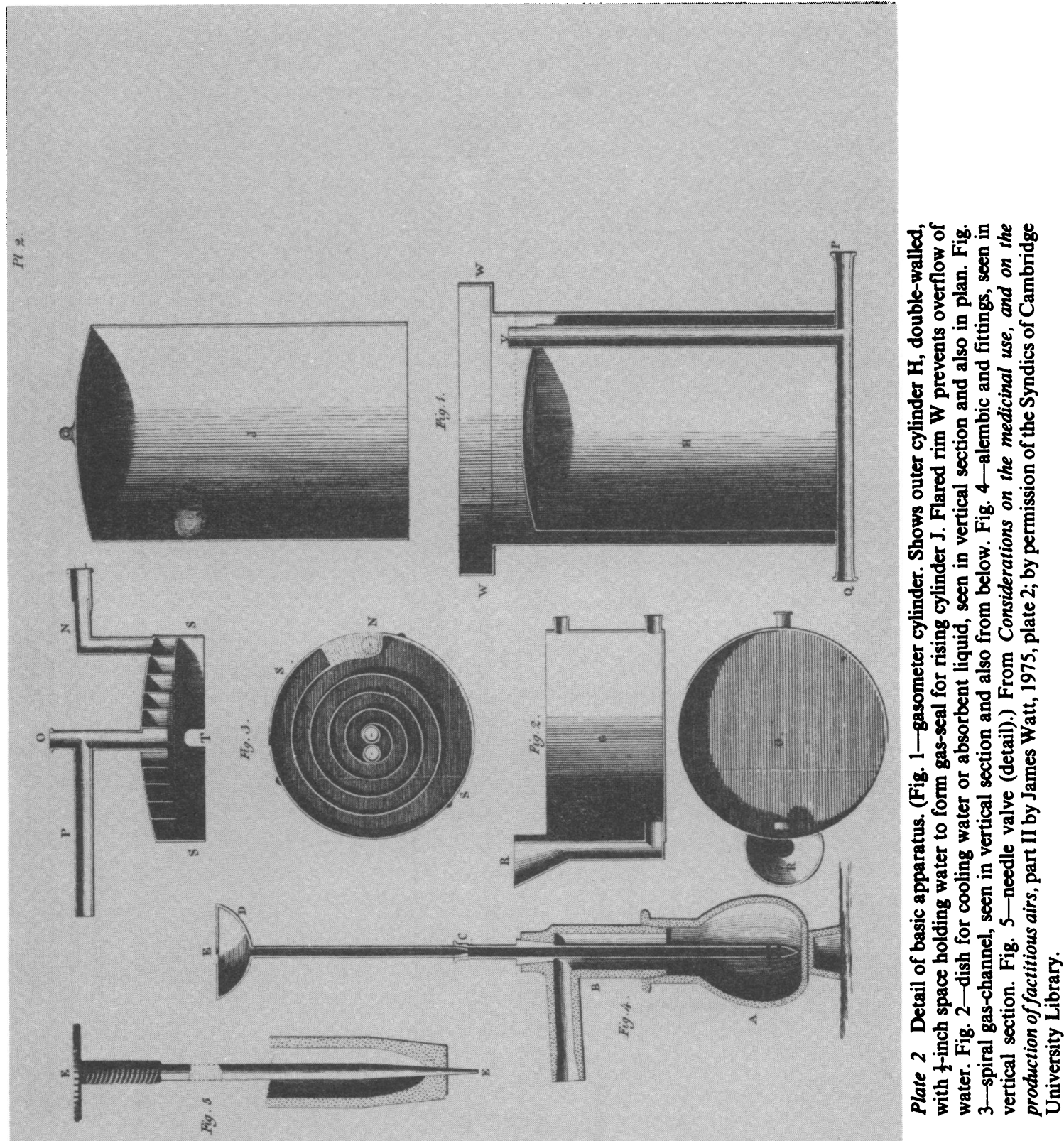


\section{R. G. Stansfield}

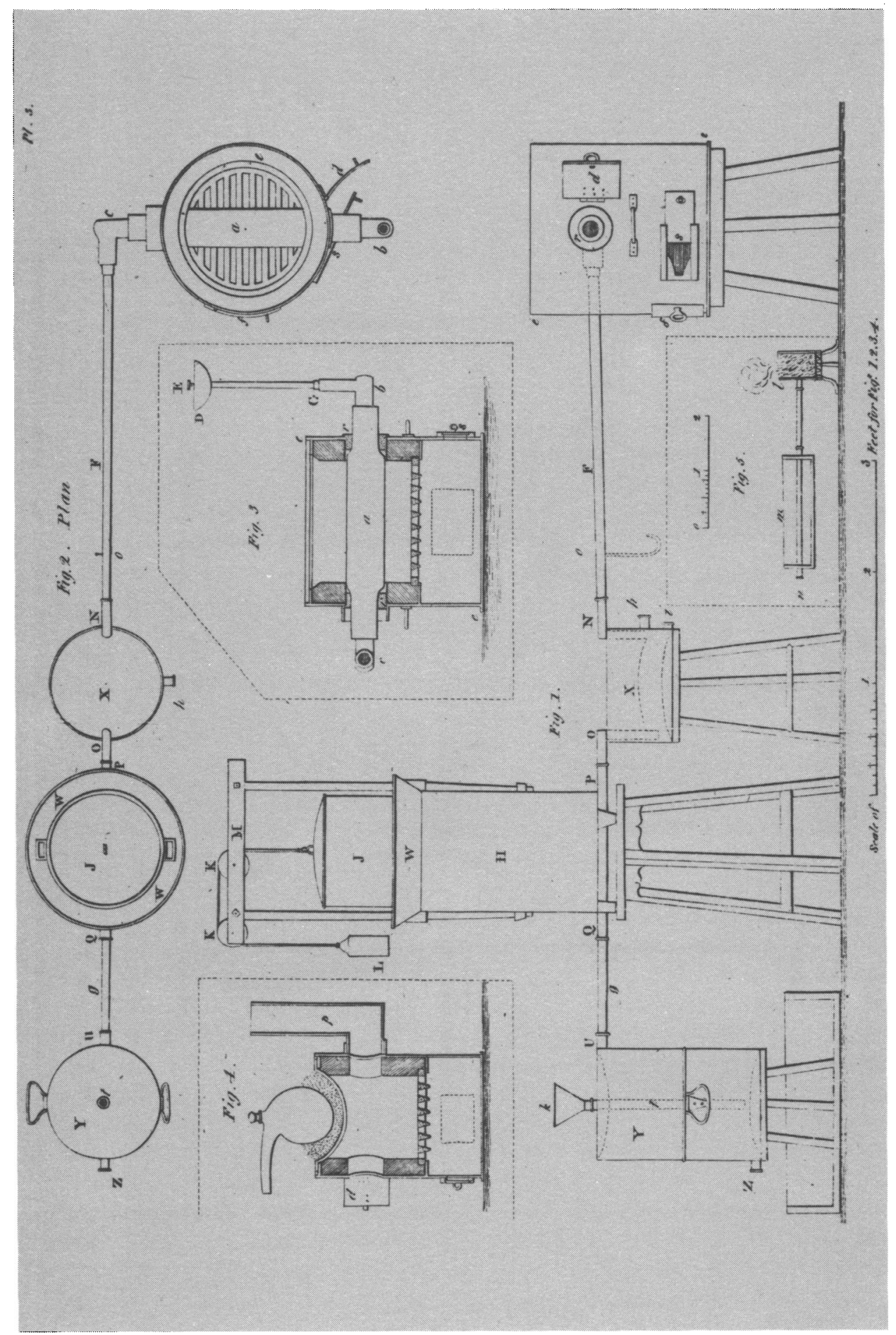

总兽 的 용

的

8.

토놇 언 氖 एक

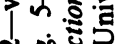
को 西这完

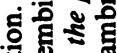
ส ㅇํㄴㅇํㅇ \% 1忽忥 一娄

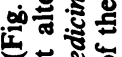
능

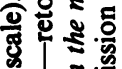
을 잉 氙的 这 क्ष 势 \% 5 ㄷํ 인운 氙它 $m$ 离

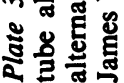

